\title{
UNDER THE "BELT AND ROAD" INITIATIVE, THE CHINA AND UKRAINE GOVERNMENTS SHOULD ASSUME GREATER RESPONSIBILITY TO PROMOTE TRADE
}

\author{
Zhao Haipeng \\ Postgraduate student \\ Sumy National Agrarian University (Sumy, Ukraine) \\ Henan Institute of Science and Technology (Henan, China) \\ ORCID: 0000-0001-5505-918X \\ Bliumska-Danko Kseniia \\ $\mathrm{PhD}$, Associate Professor \\ Sumy National Agrarian University (Sumy, Ukraine) \\ ORCID: 0000-0003-0200-2280 \\ kseniiabliumska@snau.edu.ua
}

Lu Xu

Henan Institute of Science and Technology (Henan, China)

Purpose: Ukraine is located in Eastern Europe, has a good geographical location, and has good bilateral relations and traditional economic exchanges with China, especially agriculture, high-tech, and existing and ongoing cooperation projects with China. "There are also difficulties in construction: Ukraine's economy has been in a difficult period since independence, its economic structure is very uneven, and its economic relations with Eastern European and CIS countries, as well as Russian economic relations, need to be improved. Ukraine needs to restore its national strength. China's "Belt and Road" initiative and the diplomatic concept of building a community of shared future for mankind have determined that the Chinese government is willing to help Ukraine restore its strength and restore normal political, economic, and diplomatic relations with neighboring countries. It will benefit the people through the improvement of the national economy This article aims to analyze how the two sides can use the "Belt and Road" platform to develop economic relations and strengthen cooperation to achieve mutual benefit results.

Methodology: This article uses the literature research method, the combination of analysis and synthesis methods, observation method, investigation method.

Originality: Since the Soviet Union, Ukraine has started friendly exchanges with China. After the founding of New China in 1949, Ukraine, as a part of the Soviet Union, made a greater contribution to China establishment of its national steel, machinery, agriculture and other basic industries. After Ukraine's independence, China-Ukraine relations have entered a new stage. China was the first country to recognize Ukraine's independence and established diplomatic relations with it on January 4, 1992. In the past 30 years of Ukraine's independence, the two countries have not had any conflicts of interest and no serious political and economic contradictions. The "Belt and Road" initiative proposed by Xi Jinping in 2013 provided a new platform for bilateral relations and created unprecedented opportunities for the development of bilateral relations. In the "Belt and Road" construction, Ukraine should play a greater role.

Practical value: Participating in the "Belt and Road" construction is also a very important opportunity for Ukraine, helping the Chinese people to have a more comprehensive and clearer understanding of Ukraine, and more importantly, it is conducive to the trade between the two countries to bring more Ukrainian enterprises Trade exchanges to drive the economic development of Ukraine. Politically, Ukraine and China have good bilateral relations; On June 20, 2011, the two sides signed the "China-Ukraine Joint Partnership on the Establishment and Development of Strategic Partnerships. Economically, Ukraine and China have complementary economies. Economic exchanges have been established since the Soviet Union. In recent years, the existing and ongoing cooperation between Ukraine and China has continued to develop in high-tech fields such as agriculture, machine manufacturing, and aviation. More and more Ukrainian experts have pointed out that developing relations between Ukraine and China should become a priority direction of Ukraine's current foreign policy. Ukraine has a strong advantage in agriculture, military industry, and manufacturing, especially the engine manufacturing industry, and can develop machine manufacturing; Ukraine can provide transportation for China "Belt and Road" Convenient conditions.

Keywords: Belt and Road, trade cooperation, China, Ukraine, Agricultural trade.

DOI: https://doi.org/10.32845/bsnau.2019.3.6

Introduction

Ukraine is the birthplace of the ancient "Kyiv Rus" and has a long history and civilization. Ukraine is also a young country. In the past 30 years, it has continuously explored its own development path. Ukraine established a strong industrial and agricultural foundation, The main industrial sectors include aviation, aerospace, metallurgy, machinery manufacturing, shipbuilding, and chemical engineering. Rich in grain, it has the reputation of "European Granary". In recent years, Ukraine has had a bumper harvest of grain, with output exceeding 63 million tons and exports of nearly 40 million tons. It is the world's third-largest grain exporter and the largest sunflower oil exporter. In 2014, Ukraine suffered the worst political, economic and social unrest since its independence. The economy continued to decline in 2015, and various economic indicators reached historical lows. The results of 
the 2016 series of reforms and economic revitalization measures showed little effect, and the economy stopped falling and rebounded. In 2017, various economic indicators have been restored. Industrial output value has increased by $21.84 \%$, and the inflation rate has been $13.7 \%$. The exchange rate remained relatively stable in 2017 , and the national debt rate declined from $82 \%$ in 2016 to $71.8 \%$. The unemployment rate was reduced from 2016. $9.2 \%$ of the year rose to $9.9 \%$. (Table 1 )

GDP of Ukraine from 1990 to 2018

\begin{tabular}{|c|c|c|c|c|c|}
\hline \multirow{2}{*}{ Year } & \multirow{2}{*}{ GDP, billion } & \multirow{2}{*}{ GDP, billion } & \multirow{2}{*}{ GDP increase, $\%$} & \multicolumn{2}{|c|}{ Percentage Of Ukraine } \\
\hline & & & & in the World & in $\mathrm{EU}$ \\
\hline 1990 & 93.5 & 93.5 & & 0.41 & 1.1 \\
\hline 1991 & 88.2 & 85.3 & -8.7 & 0.37 & 0.98 \\
\hline 1992 & 81.3 & 76.9 & -9.9 & 0.31 & 0.85 \\
\hline 1993 & 71.4 & 65.9 & -14.2 & 0.27 & 0.81 \\
\hline 1994 & 56.2 & 50.8 & -22.9 & 0.2 & 0.61 \\
\hline 1995 & 50.4 & 44.6 & -12.2 & 0.16 & 0.47 \\
\hline 1996 & 46.1 & 40.1 & -10 & 0.15 & 0.43 \\
\hline 1997 & 51.9 & 38.9 & -3 & 0.16 & 0.51 \\
\hline 1998 & 43.4 & 38.2 & -1.9 & 0.14 & 0.42 \\
\hline 1999 & 32.7 & 38.1 & -0.16 & 0.1 & 0.32 \\
\hline 2000 & 32.4 & 40.4 & 5.9 & 0.096 & 0.33 \\
\hline 2001 & 39.3 & 43.9 & 8.8 & 0.12 & 0.4 \\
\hline 2002 & 44 & 46.3 & 5.3 & 0.13 & 0.41 \\
\hline 2003 & 52 & 50.7 & 9.5 & 0.13 & 0.4 \\
\hline 2004 & 67.2 & 56.7 & 11.8 & 0.15 & 0.44 \\
\hline 2005 & 89.2 & 58.4 & 3.1 & 0.19 & 0.55 \\
\hline 2006 & 111.9 & 62.8 & 7.6 & 0.22 & 0.64 \\
\hline 2007 & 148.7 & 68 & 8.2 & 0.26 & 0.73 \\
\hline 2008 & 188.1 & 69.5 & 2.2 & 0.29 & 0.85 \\
\hline 2009 & 121.6 & 59 & -15.1 & 0.2 & 0.62 \\
\hline 2010 & 136 & 59.2 & 0.27 & 0.21 & 0.68 \\
\hline 2011 & 163.2 & 62.4 & 5.5 & 0.22 & 0.74 \\
\hline 2012 & 175.8 & 62.5 & 0.24 & 0.23 & 0.83 \\
\hline 2013 & 183.3 & 62.5 & -0.027 & 0.24 & 0.83 \\
\hline 2014 & 133.5 & 58.4 & -6.6 & \begin{tabular}{|l|}
0.17 \\
\end{tabular} & 0.6 \\
\hline 2015 & 91 & 52.7 & -9.8 & 0.12 & 0.48 \\
\hline 2016 & 93.4 & 54 & 2.4 & 0.12 & 0.49 \\
\hline 2017 & 112.2 & 55.3 & 2.5 & 0.14 & 0.55 \\
\hline 2018 & 130.8 & 57.2 & 3.3 & 0.15 & 0.6 \\
\hline
\end{tabular}

Data source: Institute of Macroeconomics :http://be5.biz/makroekonomika/gdp/ua.html.

Relations between China and Ukraine have developed smoothly since the establishment of diplomatic relations in 1992. In 2011, the two countries established a strategic partnership of cooperation, and bilateral cooperation in various fields continued to develop. After exceeding three billion US dollars for three consecutive years in 2011, 2012 and 2013, bilateral trade has grown by $9.9 \%$ in 2017, and China has occupied Ukraine's second-largest trading partner status for the sixth consecutive year. As of the end of 2017, China's investment stock in Ukraine was the US \$62.65 million, with no large-scale withdrawal of capital; Lenovo,
Huawei, Sany Heavy Equipment, complete sets of projects, Chinese building materials, COFCO Agriculture and other Chinese brands have continued to increase their popularity and market share in Ukraine; China-Ukraine economic and trade cooperation has withstood the test of Ukraine's political turmoil and economic recession, and bilateral economic and trade cooperation has maintained continuity. In 2018, while implementing the free trade agreement with the European Union, Ukraine continued to participate in the "Belt and Road" initiative initiated by China and actively participated in the first China Import Expo to promote exports to China.(Table 2) 
Ukraine's imports from major trading partners

\begin{tabular}{|l|l|l|l|}
\hline \multicolumn{2}{|c}{ Country } & \multicolumn{1}{c}{ Amount } & \multicolumn{1}{c}{ Unit: million dollars } \\
\hline Total & 43,972 & 7.8 & \multicolumn{1}{c|}{ Proportion \% } \\
\hline China & 6,574 & 25.8 & 100 \\
\hline Russia & 5,412 & -6.9 & 15 \\
\hline Germany & 4,499 & -0.7 & 12.3 \\
\hline Poland & 2,956 & 12.8 & 10.2 \\
\hline Belarus & 2,666 & -5.7 & 6.7 \\
\hline United States & 2,342 & 8.4 & 6.1 \\
\hline Italy & 1,450 & 1.3 & 5.3 \\
\hline Turkey & 1,441 & 26.7 & 3.3 \\
\hline France & 1,222 & 13.8 & 3.3 \\
\hline Switzerland & 1,127 & 1.7 & 2.8 \\
\hline Hungary & 902 & 1.6 & 2.6 \\
\hline Lithuania & 845 & 42.1 & 2.1 \\
\hline Czech Republic & 16.1 & 1.9 \\
\hline Japan & 841 & 29.1 & 1.9 \\
\hline Spain & 670 & 31.7 & 1.5 \\
\hline & 595 & & 1.4 \\
\hline
\end{tabular}

Data source: China's Ministry of Commerce country report

Ukraine exported USD 9.4 billion in agricultural products to Asian countries in 2019 (USD 8 billion in 2018), accounting for $42.2 \%$. Ukraine's agricultural exports to the EU amounted to US $\$ 7.5$ billion, an increase of $19 \%$ year-on-year, and to US $\$ 6.3$

billion in 2018. The EU accounts for $33.5 \%$ of Ukraine's total agricultural exports. Exports to Africa were US $\$ 3.3$ billion, a yearon-year increase of $44.3 \%$, accounting for $14.9 \%$. Exports to the CIS countries amounted to US $\$ 1.5$ billion, accounting for 6.5\%.(Table 3)

Ukraine's main trading partners' exports from January to September 2019

\begin{tabular}{|l|l|l|l|}
\hline \multicolumn{2}{|c|}{ Country } & \multicolumn{1}{c|}{ Yount $\%$} & Unit: million dollars \\
\hline Total & 37110 & 7.3 & 100.0 \\
\hline China & 2587 & 78.6 & 7.0 \\
\hline Poland & 2533 & 4.4 & 6.8 \\
\hline Russia & 2460 & -9.5 & 6.6 \\
\hline Turkey & 1860 & -0.4 & 5.0 \\
\hline Italy & 1821 & -9.3 & 4.9 \\
\hline Germany & 1784 & -17.8 & 4.8 \\
\hline Egypt & 1670 & 29.8 & 4.5 \\
\hline Netherlands & 1421 & 28.1 & 3.8 \\
\hline India & 1385 & -15.3 & 3.7 \\
\hline Hungary & 1160 & -6.2 & 3.1 \\
\hline Belarus & 1144 & 19.3 & 3.1 \\
\hline Spain & 1040 & 23.7 & 2.8 \\
\hline Romanian & 756 & -5.3 & 2.0 \\
\hline United States & 756 & 8.6 & 2.0 \\
\hline Czech Republic & 713 & & 1.9 \\
\hline \multicolumn{1}{|c|}{ Data source: China's Ministry of Commerce country report } & \\
\hline
\end{tabular}

Data source: China's Ministry of Commerce country report

\section{Literature review}

Eva Minar ciková (2016) mentioned that during the past 30 years China has been one of the countries in the world with the most rapid economic growth and the longest period of sustained high growth. However, economic growth has not stopped the growing regional inequalities and unbalanced development not only between provinces but also between areas within provinces.

Irina Nikola (2019) highlighted that the "Belt and Road" initiative adhering to the principles of openness, tolerance, and inclusiveness can effectively promote the economic development of participating countries. Since the introduction of the "Belt and Road" initiative, Ukraine-China economic and trade relations have further deepened and cooperation prospects in various fields are positive. "Participation in the" Belt and Road "initiative has strategic significance for the development of cooperation between Ukraine and China. The further deepening of economic and trade cooperation is the development of bilateral relations. major outcomes. The trade volume between Ukraine and China exceeded USD 8 billion in 2018 and is expected to reach USD 20 billion per year in the future. Ukraine 's participation in the "Belt and Road" construction is conducive to the realization of innovative development and promotes the construction of a UkraineChina joint scientific research center and an industrial park with Chinese participation. In addition, the central bank is taking a series of measures aimed at improving the investment environment and providing protection for foreign investors.

Stepan Kubiv (2017) considered that Ukraine is located at the junction of Europe and Asia and has a unique geographical 
advantage. Multiple transport corridors can provide transit services for goods to the three continents of Europe, Asia, and Africa. We should seize the opportunity to take advantage of this advantage. Ukraine should implement a series of infrastructure projects, including the construction of ports, granaries, and cold storage, the development of infrastructure will drive industrial growth, which will help Ukraine to transform from a raw material economy to an innovative investment economy. Ukraine's participation in the "Belt and Road" initiative will strengthen Ukraine's trade ties with other countries.

Victor Kiktenko (2019) underlined that the Belt and Road Initiative is very attractive to Ukraine and can bring new opportunities for Ukraine's economic development. Ukraine and China continue to tap the potential of Ukraine's participation in the Belt and Road Initiative. The focus of attention includes UzbekistanChina strategic partnership and bilateral cooperation in the fields of economy and trade, transportation, science and technology, information technology, education, culture, tourism, and media. Among them, the Uzbek government and the business community have launched trade and investment in the "Belt and Road" initiative Potential is most interesting; major scientific research institutions, universities, think tanks, and social organizations in Ukraine have also shown great interest in the "Belt and Road" initiative. In recent years, more and more papers, analytical studies and media reports have been published on this initiative.

Gennady Chirikov (2019) stressed that Ukraine and China's bilateral cooperation is getting closer, and China has become Ukraine's largest trading partner. All departments in Ukraine are studying how to strengthen cooperation with China. For example, new energy and agriculture are the focus of bilateral cooperation. Cooperation under the Belt and Road Initiative is becoming more and more important. China is one of Ukraine's most important economic partners. In recent years, the desire of the Ukrainian business community to develop practical cooperation with China has become stronger. Ukraine hopes to expand bilateral economic and trade cooperation and see more goods and services enter the markets of both sides, and then strengthen mutual investment.

Buzarov (2019) emphasized that the "Belt and Road" initiative is not a closed initiative but an open initiative, and any country can become a "Belt and Road" participant. A series of major reform and opening-up measures that China will adopt are the correct choices made in accordance with China's future development needs, and also set up an important platform for expanding international cooperation. China not only attaches importance to exports, but also attaches great importance to imports China imports foreign goods, and The company's operations in China have created good conditions and created a good investment environment. While achieving its own green development,
China also strives to cooperate with the Belt and Road participating countries in the field of environmental protection, which will help countries to jointly respond to global challenges. Challenges to sustainable development.

Professor Valery Bebik of Kyiv University (2019) mentioned that the "Belt and Road" initiative is to achieve common development and prosperity through the establishment of a global interconnected partnership. On the basis of mutual learning and learning from different civilizations, a diverse and interactive humanities exchange pattern has been formed. The "Belt and Road" will promote economic and trade relations between countries. The most important thing in international trade is that participants can benefit. The other important thing is cultural exchanges. We should learn from the civilization of other peoples and participate in the joint construction of the "Belt and Road". Participating countries will release economic potential and improve people's living standards. China is both a 'world factory' and a 'world market'. China's further expansion of reform and opening up is very attractive to foreign investors because all the "Belt and Road" All participating countries will benefit from this.

Negaruk (2017) declared that China-Ukraine production capacity cooperation has great potential and is highly complementary. The 'Belt and Road' construction has brought new opportunities to the development of Ukrainian enterprises. Ukraine is an important gateway for Chinese companies to enter the European market. With the development of the "Belt and Road" initiative, more and more Chinese enterprises are going overseas along the "Belt and Road". While exploring the Ukrainian market, they are also sharing the successful experience of China's development with Ukrainian enterprises. Ukraine's new government is advancing judicial reform, and local governments have gradually increased their awareness of protecting the interests of foreign investors.

\section{The purpose of the article}

According to data released by the National Bureau of Statistics of the People's Republic of China on January 17, 2020, the total population of mainland China exceeded 1.4 billion people, China is a super populous country, with $7 \%$ of the world's land resources, raising $22 \%$ of the world's population. With a huge population base, that the supply of market products cannot meet the growing population demand. Especially after the 2008 financial crisis, the international commodity markets plummeted, and the world 's major agricultural exporters tried to open the Chinese market. Through the China-Ukraine cooperation agreement, Ukraine provided a legal basis for its agricultural products to enter the Chinese market; With the joint efforts of both governments, Ukraine provided policy, technical and financial support for business cooperation.(Table 4) 
Annual and monthly table of Ukraine's foreign trade

\begin{tabular}{|c|c|c|c|c|c|c|c|c|}
\hline \multicolumn{9}{|c|}{ Unit: million dollars } \\
\hline Time/year & Amount & YoY \% & Export & YoY \% & Import & YoY \% & Difference & YoY \% \\
\hline 2002 & 34,934 & -79 & 17,957 & -78.1 & 16,977 & -79.8 & 980 & -148.8 \\
\hline 2003 & 46,101 & 32 & 23,080 & 28.5 & 23,021 & 35.6 & 59 & -93.9 \\
\hline 2004 & 61,668 & 33.8 & 32,672 & 41.6 & 28,996 & 26 & 3,676 & $6,087.30$ \\
\hline 2005 & 70,428 & 14.2 & 34,287 & 4.9 & 36,141 & 24.6 & $-1,854$ & -150.4 \\
\hline 2006 & 83,402 & 18.4 & 38,368 & 11.9 & 45,035 & 24.6 & $-6,667$ & 259.5 \\
\hline 2007 & 109,918 & 31.8 & 49,248 & 28.4 & 60,670 & 34.7 & $-11,422$ & 71.3 \\
\hline 2008 & 152,537 & 38.8 & 67,003 & 36.1 & 85,535 & 41 & $-18,532$ & 62.2 \\
\hline 2009 & 85,138 & -44.2 & 39,703 & -40.7 & 45,436 & -46.9 & $-5,733$ & -69.1 \\
\hline 2010 & 112,170 & 31.8 & 51,431 & 29.5 & \begin{tabular}{|l|}
60,740 \\
\end{tabular} & 33.7 & $-9,309$ & 62.4 \\
\hline 2011 & 151,017 & 34.6 & 68,410 & 33 & 82,607 & 36 & $-14,197$ & 52.5 \\
\hline 2012 & 153,343 & 1.5 & 68,685 & 0.4 & 84,658 & 2.5 & $-15,973$ & 12.5 \\
\hline 2013 & 140,276 & -8.5 & 63,312 & -7.8 & 76,964 & -9.1 & $-13,652$ & -14.5 \\
\hline 2014 & 108,295 & -22.8 & \begin{tabular}{|l|}
53,914 \\
\end{tabular} & -14.8 & \begin{tabular}{|l|}
54,382 \\
\end{tabular} & -29.3 & -468 & -96.6 \\
\hline 2015 & 75,637 & -30.2 & 38,135 & -29.3 & 37,502 & -31 & 633 & -235.1 \\
\hline 2016 & 75,552 & -0.1 & 36,373 & -4.6 & 39,180 & 4.5 & $-2,807$ & -543.7 \\
\hline 2017 & 92,766 & 22.8 & 43,301 & 19 & 49,465 & 26.3 & $-6,165$ & 119.6 \\
\hline 2018 & 104,192 & 12.3 & 47,372 & 9.4 & 56,820 & 14.9 & $-9,448$ & 53.3 \\
\hline 2019,1-9Month & 81,082 & 7.6 & 37,110 & 7.3 & \begin{tabular}{|l|}
43,972 \\
\end{tabular} & 7.8 & $-6,861$ & 10.5 \\
\hline January & 8,111 & 4.8 & 4,066 & 9.2 & 4,045 & 0.8 & 21 & 107.2 \\
\hline February & 8,564 & 10.72738 & 3,893 & 6.59 & 4,671 & 14.43 & -777 & 81.1 \\
\hline March & 9,266 & 7.7409745 & 4,323 & 6.5 & 4,943 & 8.85 & -621 & 28.6 \\
\hline April & 8,793 & 7.3357367 & 4,092 & 1.67 & 4,701 & 12.8 & -609 & 325.9 \\
\hline May & 9,592 & 10.901655 & 4,533 & 12.95 & 5,058 & 9.13 & -525 & -15.6 \\
\hline June & 8,229 & \begin{tabular}{|l|}
0.3393559 \\
\end{tabular} & 3,575 & -5.96 & 4,654 & 5.78 & $-1,080$ & 80.4 \\
\hline July & 9,737 & 13.638013 & 4,279 & 18.25 & 5,458 & 10.27 & $-1,179$ & -11.4 \\
\hline August & 9,460 & 6.0342088 & 4,284 & 6.13 & 5,175 & 5.95 & -891 & 5.1 \\
\hline September & 9,330 & 6.5785801 & 4,065 & 11.57 & 5,265 & 3.02 & $-1,201$ & -18.2 \\
\hline
\end{tabular}

Data source: China's Ministry of Commerce country report

(Table 5)

Ukraine's main trading partners' exports 2019

\begin{tabular}{|c|c|c|c|}
\hline Country & Amount & YoY\% & Percentage \\
\hline Total & 37110 & 7.3 & 100.0 \\
\hline China & 2587 & 78.6 & 7.0 \\
\hline Poland & 2533 & 4.4 & 6.8 \\
\hline Russia & 2460 & -9.5 & 6.6 \\
\hline Turkey & 1860 & -0.4 & 5.0 \\
\hline Italy & 1821 & -9.3 & 4.9 \\
\hline Germany & 1784 & -17.8 & 4.8 \\
\hline Egypt & 1670 & 29.8 & 4.5 \\
\hline Netherlands & 1421 & 28.1 & 3.8 \\
\hline India & 1385 & -15.3 & 3.7 \\
\hline Hungary & 1160 & -6.2 & 3.1 \\
\hline Belarus & 1144 & 19.3 & 3.1 \\
\hline Spain & 1040 & 23.7 & 2.8 \\
\hline Romanian & 756 & 7.3 & 2.0 \\
\hline United States & 756 & -5.2 & 2.0 \\
\hline Czech Republic & 713 & 8.6 & 1.9 \\
\hline
\end{tabular}

Data source: China's Ministry of Commerce country report 


\begin{tabular}{|c|c|c|c|}
\hline \multicolumn{2}{|c|}{ Unit: million dollars } \\
\hline Country & Amount & YoY\% & 100 \\
\hline Total & 43,972 & 7.8 & 15 \\
\hline China & 6,574 & 25.8 & 12.3 \\
\hline Russia & 5,412 & -6.9 & 10.2 \\
\hline Germany & 4,499 & -0.7 & 6.7 \\
\hline Poland & 2,956 & 12.8 & 6.1 \\
\hline Belarus & 2,666 & -5.7 & 5.3 \\
\hline United States & 2,342 & 8.4 & 3.3 \\
\hline Italy & 1,450 & 1.3 & 3.3 \\
\hline Turkey & 1,441 & 26.7 & 2.8 \\
\hline France & 1,222 & 13.8 & 2.6 \\
\hline Switzerland & 1,127 & 1.7 & 2.1 \\
\hline Hungary & 902 & 1.6 & 1.9 \\
\hline Lithuania & 845 & 42.1 & 1.9 \\
\hline Czech Republic & 841 & 16.1 & 1.5 \\
\hline Japan & 670 & 29.1 & 1.4 \\
\hline Spain & 595 & 31.7 & \\
\hline
\end{tabular}

Data source: China's Ministry of Commerce country report

The main source of the above data is the country trade report of the Ministry of Commerce of the People's Republic of China, which shows that China-Ukraine trade has been frequent in recent years, and the future development and prospects are good;

\section{Research methodology}

This article adopts the literature research method. By collecting, identifying, and collating the literature of scholars at home and abroad, and by studying the literature, it forms a scientific understanding of facts, collects statistical data on China-Ukraine import and export trade, and sorts out the "Belt and Road" initiative. To find preferential policies that are suitable for Ukraine, to objectively describe and compare Ukraine and China's regional economic and regional policy issues, and to use the combination of analysis and integration to the main aspects of China-Uzbekistan trade cooperation, the results, and future prospects. The methods of observation and investigation, combined with the results of analysis through trade data, put forward the problems and factors affecting development in the trade development between China and Ukraine under the "Belt and Road" initiative. The data used in this article comes from the country trade report of the Ministry of Commerce of the People's Republic of China, the Economic and Commercial Office of the Embassy of the People's Republic of China in Ukraine, and the Ministry of Commerce's foreign investment and economic cooperation.

Results and discussion

Future development space for China-Ukraine economic \& trade cooperation.

Ukraine's various advantages determine that Ukraine is an important node of the "Belt and Road". Ukraine's participation in the "Belt and Road" to carry out bilateral economic and trade cooperation has significant comparative advantages, such as geographical location, markets, labor costs, science and technology, and industrial and agricultural foundation. So why do many Chinese-funded enterprises have a strong interest and high enthusiasm for economic and trade cooperation with Ukraine, but are cautious? What exactly is the investment and trade environment in Ukraine? What are the risks? What is the relationship between China and Ukraine? What is Ukraine's appeal to China?

\section{Ukraine's comparative advantage}

Ukraine is the largest market in Eastern Europe. In addition, Ukraine is also close to the EU, Eurasian and North African markets. Ukraine has signed FTA agreements with the European Union and 13 countries to provide preferential tariff rates to each other. Ukraine has excellent natural conditions for developing agriculture. There is huge potential for agricultural development and exports. If high technology can be introduced and the product structure adjusted, the efficiency of production capacity will be greatly improved.

Ukraine's export value reached 59.1 billion US dollars in 2018, ranking 53rd in the world. Ukraine's export value was 11.2 billion US dollars less than Ukraine's imports. The trade deficit accounted for $8.6 \%$ of Ukraine's GDP. Ukraine's share of world exports is $0.24 \%$.

Ukraine is rich in natural resources, and its exports are still dominated by ferrous metals, raw materials, and agricultural products. Its economic development is extremely vulnerable to the influence of international market conditions. Ukraine's oil and gas resources are relatively scarce, and about $40 \%$ are still dependent on imports.

Ukraine has a solid industrial foundation, and aviation, aerospace, military, shipbuilding, communications, and other sectors have technological advantages. Ukraine

2. Main risks of economic and trade cooperation with

For investors, Ukraine is quite attractive, but the risks cannot be underestimated. The Ukrainian crisis actually has three levels:

The first level is the geopolitical crisis; Ukraine is in the collision zone of geopolitical competition between Russia and the West, and external factors have greatly affected its stability and development. In the short term, the possibility of a full-scale war between Russia and Ukraine is unlikely, and local conflicts may be intermittent, but it is extremely unlikely that they will spread to Kyiv.

The second level is the political crisis in Ukraine. Will the "square revolution" happen again in Ukraine? The political development in Ukraine since 2014 shows that former president Poroshenko's ability to control the situation during the administration has significantly increased, which has imposed a certain degree of restraint on the government, the opposition and local forces, 
and the risk of another political crisis has dropped significantly; The situation in Ukraine has stabilized. However, oligarchs still play a major role in politics.

The third level is the economic crisis. In terms of economic indicators, the Ukrainian economy has come out of the bottom and started to recover slowly. In recent years, the Ukrainian government has adopted a series of measures to attract investment and achieved certain results. According to the World Bank's Global Business Environment Report, Ukraine's ranking rose from 112th in 2013 to 76th in 2017.

Table 7

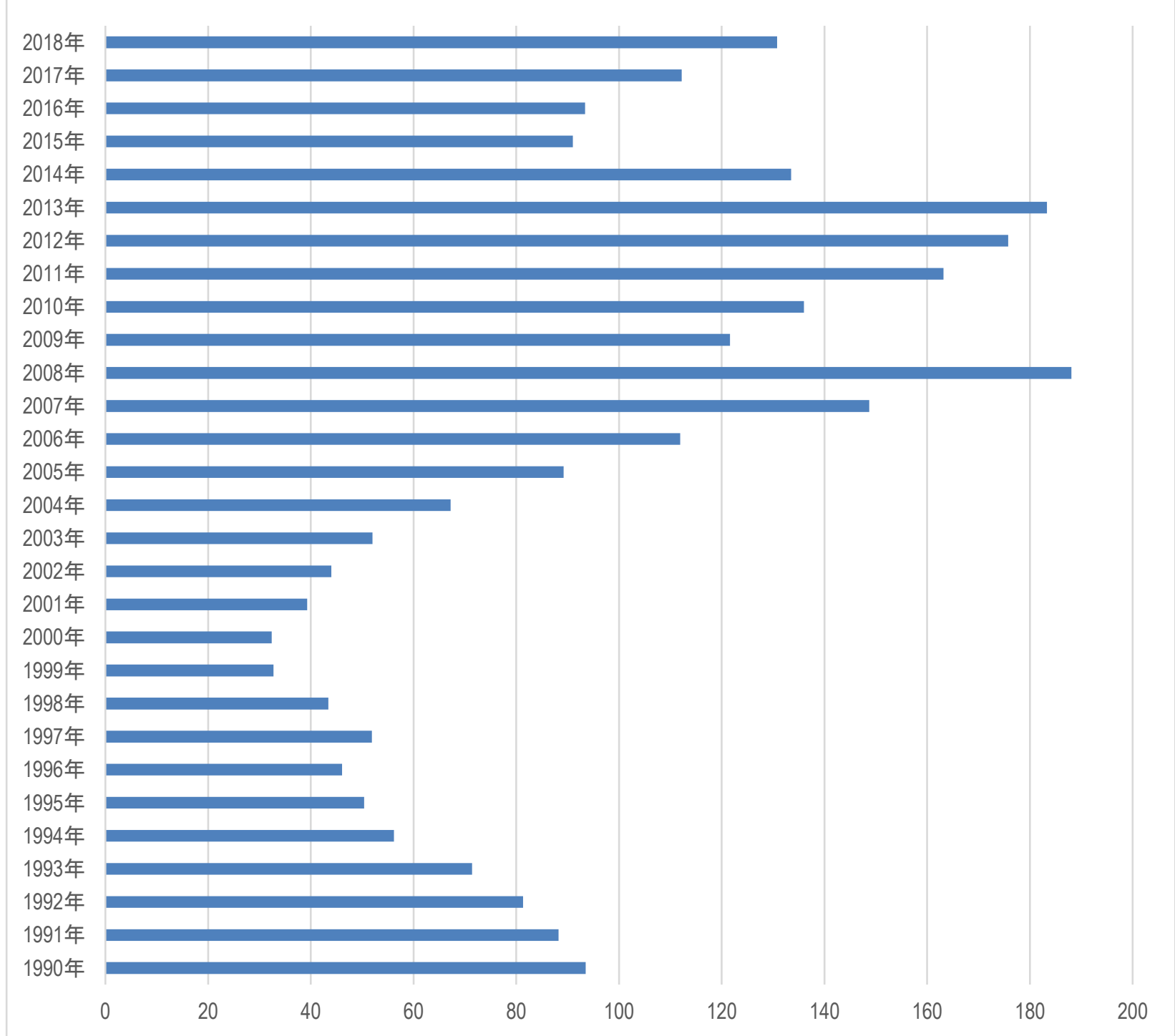

Data Sources: Macroeconomic Research : http://be5.biz/makroekonomika/gdp/ua.html.

Table 7 shows that within a few years after the collapse of the Soviet Union, Ukraine's gross domestic product experienced a "down all the way" and began to rise after 2005. The world economic crisis in 2008 had a certain impact on the Ukrainian economy in 2009, and the GNP fell again. When 2013 had not (Table 8)

recovered to the 2008 level, it fell again from 2014 to 2016 . It can be seen that Ukraine's economy is highly dependent on the external environment. At the same time, Ukraine's economic selfrecovery ability is not very strong, which also makes every external shock bring great trauma to the Ukrainian economy.

\section{Exports of Ukraine and neighboring countries, attitudes towards Ukrainian indicators}

\begin{tabular}{|c|c|c|c|c|}
\hline Country & 1990 & $\mathbf{2 0 0 0}$ & $\mathbf{2 0 1 0}$ \\
\hline Russia & 0.64 & 0.77 & 0.84 \\
\hline Poland & -0.16 & 0.38 & 0.48 \\
\hline Hungary & -0.43 & 0.21 & 0.22 \\
\hline Romanian & -0.6 & -0.2 & -0.075 \\
\hline Ukraine & 0 & 0 & 0.74 \\
\hline Bulgaria & -0.54 & -0.61 & -0.4 & -0 \\
\hline Belarus & -0.46 & -0.46 & -0.34 & -13 \\
\hline Moldova & -1.2 & -1.6 & -1.5 & -1.2 \\
\hline
\end{tabular}


(Table 9)

Per capita exports of Ukraine and surrounding countries

\begin{tabular}{|c|c|c|c|c|}
\hline Country & $\mathbf{1 9 9 0}$ & $\mathbf{2 0 0 0}$ & $\mathbf{2 0 1 0}$ & $\mathbf{2 0 1 8}$ \\
\hline Hungary & 1.8 & 7.7 & 7.7 & 10.3 \\
\hline Poland & 0.93 & 3 & 3.6 & 6.4 \\
\hline Bulgaria & 1.7 & 1.5 & 2.5 & 4.6 \\
\hline Romanian & 0.55 & 1.4 & 1.9 & 3.8 \\
\hline Belarus & 1.7 & 1.7 & 2.2 & 3.3 \\
\hline Russia & 1.5 & 2 & 2.2 & 2.6 \\
\hline Ukraine & 1 & 1 & 1 & 1 \\
\hline Moldova & 0.74 & 0.32 & 0.34 & 0.63 \\
\hline
\end{tabular}

(Table 10)

\begin{tabular}{|c|c|c|c|c|}
\hline \multicolumn{5}{|c|}{ Export comparison between Ukraine and major countries } \\
\hline Country & 1990 & 2000 & 2010 & 2018 \\
\hline China & 0.35 & 1.2 & 1.4 & 1.7 \\
\hline United States & 1.3 & 1.7 & 1.5 & 1.6 \\
\hline Germany & 1.2 & 1.5 & 1.4 & 1.5 \\
\hline Japan & 1.1 & 1.4 & 1.1 & 1.2 \\
\hline France & 1 & 1.3 & 1 & 1.2 \\
\hline Ukraine & 0 & 0 & 0 & 0 \\
\hline
\end{tabular}

(Table 11)

\begin{tabular}{|c|c|c|c|c|}
\hline Export comparison between Ukraine and major countries \\
\begin{tabular}{|c|c|c|c|c|}
\hline Country & $\mathbf{1 9 9 0}$ & $\mathbf{2 0 0 0}$ & $\mathbf{2 0 1 0}$ & $\mathbf{2 0 1 8}$ \\
\hline China & 0.35 & 1.2 & 1.4 & 1.7 \\
\hline United States & 1.3 & 1.7 & 1.5 & 1.6 \\
\hline Germany & 1.2 & 1.5 & 1.4 & 1.5 \\
\hline Japan & 1.1 & 1.4 & 1.1 & 1.2 \\
\hline France & 1 & 1.3 & 1 & 0 \\
\hline Ukraine & 0 & 0 & 0 & \\
\hline
\end{tabular}
\end{tabular}

Data source: Institute of Macroeconomics, http://be5.biz/makroekonomika/export/ua.html

The above data: Ukraine's export potential in 2018. If the per capita export value is the same as that of Germany (US $\$ 22,756.4)$, Ukraine's export value will be US $\$ 10,014$ billion, which is 16.9 times the actual level. If the per capita export value is the same as the per capita export value of Hungary, Hungary's better neighbor, (13,840.8 US dollars), Ukraine's export value will reach 609.1 billion US dollars, 10.3 times the actual level. If the per-capita export rate is the same as European per-capita exports (US \$ 1341.6), Ukraine's export value will reach US \$ 590.4 billion, which is 10.0 times the actual level. If the per capita export rate is the same as that of Eastern Europe (\$5,176.4), Ukraine's export value will reach $\$ 227.8$ billion, which is 3.9 times the actual level. If the per capita export value is the same as the world's per capita export value $(\$ 32,870.7)$, Ukraine's export value will be $\$ 144.4$ billion, which is 2.4 times the actual level. China

3. China-Ukraine Relations and Ukraine's Appeal to

China and Ukraine have a good political basis for economic and trade cooperation. There are no problems left over from history or geopolitical conflicts between the two countries. In terms of its China policy, Ukraine first hopes that China will give Ukraine stronger support on the Crimea and eastern Ukraine issues. Some Ukrainian officials and scholars believe that China should also be able to stop Russia's aggression against Ukraine. China 's diplomatic focus is on building a new type of great-power relations, building a community of shared future for mankind, and building a global partnership, China always respects Ukraine's national sovereignty, independence, and territorial integrity, and supports Ukraine in taking a development path that suits its national conditions. Despite the differences in the primary demands of China-Ukraine diplomacy, neither side has given up on promoting cooperation; In fact, Ukraine's export development strategy and policies can be fully linked with the "Belt and Road", and the two sides also have great potential in the areas of financing and public relations. As of March 2018, Ukraine has not participated in the Asian Infrastructure Investment Bank, nor has it signed a strategic docking document, an infrastructure cooperation agreement and a capacity cooperation agreement with China. Many elites in Ukraine do not know China, and they still have doubts about China 's proposal to build a free trade zone, industrial parks, and renting land to grow grain.

\section{Conclusions}

The construction of the "Belt and Road" is a long process, so we must not rush to achieve success, but must do basic work down to earth. Steady progress will be made in areas where conditions are ripe, and consensus will need to be accumulated in areas where conditions are poor. Promoting the construction of the "Belt and Road" is a win-win situation for all parties, so cohesion of consensus also requires multi-party efforts.

What China can share with the Eurasian countries, including Ukraine, is more about opportunities and experiences brought about by economic growth. China's "Belt and Road" initiative is to share the achievements of China in the 30 years of reform and openness through "Policy Link, Facilities Link, Trade Link, Capital Link, and People's Link", and build the "Community of Interests and Destiny" advocated by President Xi Jinping Community and Community of Responsibility. "

Second, attach importance to the building of political mutual trust and cooperation mechanisms. Promote the establish- 
ment of bilateral cooperation mechanisms; from case-to-case cooperation to mechanism construction, expand the basis of bilateral cooperation. Since the "Belt and Road" initiative was introduced, certain results have been achieved in Kazakhstan, Belarus, Pakistan, Georgia, and other countries. Here, thanks to the policy docking between bilateral governments, through the establishment of an intergovernmental cooperation mechanism system. Including strategic docking (China's Kazakhstan Bright Road and Belt and Road docking; China Pakistan Pakistan-China Economic Corridor), Industrial Park (China-Belarus Industrial Park Plan), Free Trade Agreement (China Georgia Free Trade Agreement). Therefore, how to connect the mechanisms is a question that China and Ukraine need to consider to enhance cooperation in the Belt and Road Initiative. At present, high-level leaders between the two governments have few opportunities to meet and fail to build the necessary political mutual trust. The level and scope of cooperation mechanisms between governments need to be improved.

Adhere to market principles and improve the business en- vironment. The "Belt and Road" is a bilateral and multilateral cooperation plan and a link for cultural cooperation and exchanges. It requires not only political mutual trust but also market principles. The main content of the Belt and Road Initiative is in-depth economic cooperation. Successful cooperation must rely on the market and must act in accordance with market rules. Ukraine improves its business environment, considers bilateral cooperation from the perspective of the market, and creates better investment and trading conditions. According to the cleanliness index published by Transparency International, it is still not optimistic. In 2017 , it ranked 135th in the world, only less than the crisis. The previous 144 places in 2013 rose slightly, and Ukraine still improved its ranking in the world 's business-friendly reading. Looking at the ease of doing business in the Global Business Environment Report published by the World Bank every year, it increased 16 places in 2015 to 189 . Each of the participating countries ranked 96, and the 2016 index ranked 83rd in the world. Compared with developed countries, Ukraine still has a lot of room for improvement in its business environment.

\section{References:}

1. Zhao Huirong,Status and Development Prospects of China-Ukraine Economic and Trade CooperationProspects and Obstacles of Ukraine-China Economic and,Trade Relations,Ukraine \& China,No.13,2018,http://sinologist.com.ua/wp-content/uploads/2018/10/ukraine-china-n13-2018.pdf

2. Stepan Kubiv,"Belt And Road" is a Big Opportunity for Ukraine,Xinhua News Agency,2017.10.05(1), www.xinhuanet.com/world/2017-10/05/c_1121763877.htm

3. Linde GOETZ, Harald GRETHE,The entry price system for fresh fruit and vegetable exports from China to the EUBreaking a fly on the wheel?,China Economic Review,Vol.21, No.3,pp377-393.doi:10.1016/j.chieco.2010.02.001

4. Institute of international trade and economic cooperation, ministry of commerce, Guide for country (region) of foreign investment cooperation,(2018),https://www.yidaiyilu.gov.cn/wcm.files/upload/CMSydylgw/201902/201902010436030.pdf

5. Sheikh Kosevoj, Lee Junsheng,"Belt and Road": the experience of some countries in the world and the prospects of Ukraine, Russian Academic Journal,2016(4)

6. Colin Flinta, Cuiping Zhu,(2019)The geopolitics of connectivity, cooperation, and hegemonic competition:The Belt and Road Initiative,Geoforum,Vol.99,pp,95-101.doi.org/10.1016/j.geoforum.2018.12.008

7. Li Li,Michael Dunford,Godfrey Yeung,(2012),International trade and industrial dynamics:Geographical and structural dimensions of Chinese and Sino-EU Merchandisetrade,Applied Geography,Vol.32,No.1,pp,130-142.doi:10.1016/j.apg eog.2010.10.017

8. Leonard K. Cheng,(2016), Three questions on China's "Belt and Road Initiative" China Economic Review,Vol.40,pp,309313.doi.org/10.1016/j.chieco.2016.07.008

9. Dong Yanga, Liping Jiangb, Adolf K.Y. Ng,(2018),One Belt one Road, but several routes: A case study of new emerging trade corridors connecting the Far East to Europe, Transportation Research Part A,Vol.11pp,190-204.doi.org/10.1016/j.tra.2018.08.001

10. Xin Wen, Hoi-Lam Ma, et al,(2019),Impacts of the Belt and Road Initiative on the China-Europe trading route selections, Transportation Research Part E,Vol.pp, 581-604.doi.org/10.1016/j.tre.2019.01.006

11. Lars Oxelheim,Pervez Ghauri,(2008),EU-China and the non-transparent race for inward FDI,Journal of Asian Economics,Vol.19,No.4pp, 358-370. doi:10.1016/ j.asieco. 2008.04.001

12. Tan Wujun,Be a stickman of the "Belt and Road" construction in China and Ukraine ("Belt and Road", mutual benefit and reciprocity),People's daily,2017.05.06, http://world.people.com.cn/n1/2017/0506/c1002-29257756.html

13. Chi Gong,Soyoung Kim,(2018),Regional business cycle synchronization in emerging and developing countries: Regional or global integration?,Trade or financial integration ,Vol.84,pp,42-57.doi.org/10.1016/j.jimonfin.2018.02.006

14. Yiping Huang,(2016),Understanding China's Belt \& Road Initiative: Motivation, framework and assessment,China Economic Review,Vol.40,pp,314-321.doi.org/10.1016/j.chieco.2016.07.007.

15. Zhang Hong,Belt And Road: Risks and Responses to Cooperation Between China and Ukraine, Kytaieznavchi doslidzhennia, 2017, No.1-2,pp.61-72,http: //politics. people.com.cn/GB/n1/2017/0515/c1024-29274490.html

16. Eva Minarcíková,(2016),EU-China cooperation on regional policy,ScienceDirect, Vol.7,pp,3038.doi.org/10.1016/j.pisc.2015.11.007.

17. Li Yan,China-Ukraine Cooperation under the Belt and Road Initiative: Status and Prospect,Ukraine-China,no.13, (2018),sinologist.com.u

18. Ruslan Lenivsky,(2019),My goal is to attract more Chinese investment and improve the status quo of the Ukrainian economy. At the same time, let Chinese investors feel Ukrainian political stability,Ukraine-China,No.18(4),2019, http://sinologist. com.ua/zh/category/publications-ch/journal-ukraine-china-zh/ukr-ch-2019-18/ 
19. Valery Bebek,Ukraine,the belt and road initiative Mmutual Benefit,CNTV,2019.04.27 https://baijiahao.baidu.com/s?id=1631958131096829984\&wfr=spider\&for=pc

20. Zhang Jun bin, The initiative stems from China's efforts to share its benefits globally, China youth daily, 2019.12.11(1), https://zqb.cyol.com/html/2019-12/11/nw.D110000zgqnb_20191211_3-01.htm

21. Ukrainian Sinologists Association,Ukraine\&China, 2017(4),

22. Maria SILGONER, Katharina STEINER, et al,(2014),Fishing in the same pool:Export strengths and competitiveness of China and Central, Eastern and Southeastern Europe at the EU-15 market,China Economic Review, Vol.32, pp.68-83.doi.org/ 10.1016/j.chieco.2014.11.001

23. In the "Business Environment Report 2016" published by the World Bank,Website of the Ministry of Commerce, 2015.11.01, http://www.mofcom.gov.cn/article/i//iyil/e/201511/20151101152880.shtml

24. National Development and Reform Commission Website,Co-building One Belt And One Road, concept practice and China's contribution, 2017.05.11, http://www.ndre.gov.cn/gzdt/201705/t20170511 847228.html

25. Maria Garronea,Dorien Emmers,(2019),Jobs and agricultural policy: Impact of the common agricultural policy on EU agricultural employment,Food Policy, Vol.87,pp,1-17.doi.org/10.1016/j.foodpol.2019.101744

26. François de Soyres,Alen Mulabdic,(2019),How much will the Belt and Road Initiative reduce trade costs? International Economics,Vol.159,pp,151-164 doi.org/10.1016/j.inteco.2019.07.003

27. Yabo Zhao,Xiaofeng Liu,et,al,Energy relations between China and the countries along the Belt and Road:An analysis of the distribution of energy resources and interdependence Relationships, Renewable and Sustainable Energy Reviews, Vol.107,pp,133144,doi.org/10.1016/j.rser.2019.03.007

28. Danko, Y. I., \& Reznik, N. P. (2019). Contemporary Challenges for China and Ukraine and Perspectives for Overcoming these Challenges. Global Trade and Customs Journal, 14(6), 303-307.

Чжао Хайпень, аспірант, Сумський національний аграрний університет (Суми, Україна) Хенанський університет науки і технологій (Хенань, Китай)

Блюмська-Данько К.В., к.е.н., доцент, Сумський національний аграрний університет (Суми, Україна)

Лу Ху, Хенанський університет науки і технологій (Хенань, Китай)

Можливості підтримки торгівлі між Китаєм та Україною в рамках ініціативи «Один пояс, один шлях»

Україна розташована у Східній Європі, має гарне географічне положення та має хороші двосторонні відносини та традиційний економічний обмін з Китаєм, особливо в сфері сільського господарства, точних технологій. Україно-китайська ініціатива " Один пояс, один шлях " та дипломатична концепція побудови спільного майбутнього людства визначили, що китайський уряд готовий допомогти Україні відновити свої сили та відновити нормальні політичні, економічні та дипломатичні відносини із сусідніми країнами. Ця стаття має на меті проаналізувати, як обидві сторони можуть використовувати платформу "Один пояс, один шлях" для розвитку економічних відносин та зміцнення співробітництва для досягнення взаємної вигоди.

Практична цінність: Участь у міжнародній стратегії "Один пояс, один шлях" - це можливість для України допомогти китайському народові краще розуміти Україну, і що ще важливіше, це сприяє торгівлі між країнами,дає можливість залучить більше українських підприємств, У політичному плані Україна та Китай мають хороші двосторонні відносини, 20 червня 2011 р. Сторони підписали "Китайсько-Українське спільне партнерство щодо створення та розвитку стратегічних партнерств.. В останні роки існуюча та тривала співпраця між Україною та Китаєм продовжує розвиватися у галузях високих технологій, сільському господарстві, машинобудуванні та авіації. Все більше українських експертів зазначають, що розвиваються відносини між Україною та Китаєм має стати пріоритетним напрямком поточної зовнішньої політики України: Україна має сильну перевагу в сільському господарстві, військовій промисловості та виробництві, особливо в галузі виробництва двигунів, і може розвивати машинне виробництво; Україна може забезпечити зручні умови для Китаю в "Один пояс, один шлях".

Ключові слова: «Один пояс, один шлях», торговельне співробітництво, Україна, торгівля сільськогосподарською продукцією.

Дата надходження до редакції: 15.07.2019 р. 